\title{
Copro-ELISA Prevalence of Fasciola hepatica in Cattle in Van, Turkey
}

\author{
Aysegul Bostanci \& Bekir Oğuz
}

\begin{abstract}
Background: Fasciolosis is an important food borne zoonotic disease caused by Fasciola trematode parasites. There are two types of Fasciola spp. namely F. hepatica and F. gigantica, widely distributed across the globe, affecting both human and animal hosts. In endemic regions, it is possible to base the diagnosis of fasciolosis on clinical signs and the season, however, it could be more useful to support these data with fecal examination and various hematologic and serological tests. The aim of this study was to determine the prevalence of fasciolosis in cattle in Van province by copro-ELISA technique. Materials, Methods \& Results: Fecal samples from 140 cattle were technically collected and examined by sedimentationzinc sulphate flotation technique. Modified McMaster sedimentation technique was applied to the egg positive samples to determine the EPG values. Fasciola hepatica coproantigens in samples were investigated by ELISA. The coprological and antigen ELISA prevalence of fasciolosis were determined as 5.07\% and 30.7\%, respectively, which shows the significant difference between these methods in examining the rate of infection. The highest prevalence of fasciolosis infection was observed in 1-2 age groups (41.9\%), and this prevalence was followed by $3-5(31.2 \%)$ and $\leq 6$ age group (5\%). The differences between age groups were found significant $(P<0.05)$. The prevalence in female and male cattle was found as $30.1 \%$ and $35.3 \%$ This difference was not found statistically significant $(P>0.05)$. The highest prevalence was observed in Brown Swiss with the ratio of $40 \%$ and this was followed by $31 \%$ in Crossbreed and $22.6 \%$ in Rubia Gallega. The differences among breeds were not statistically significant $(P>0.05)$.

Discussion: Fasciola hepatica is the most common species of liver flukes, and its pathogenicity leads to significant impact on the economy of the livestock industry. The economic losses consist of costs of anthelmintics, drenches, labor, liver condemnation at meat inspection; and losses in production due to mortality, reduction in meat, milk and reduction in growth rate, fertility and decreased feed intake, conversion and lower resistance to other disease.To diagnose fasciolosis, eggs can only be detected in feces after the tenth or twelfth week of infection once the parasites have matured. It is reported that routine microscopic methods used before this stage do not provide sufficient information about the current infection status. Therefore, serological tests have been introduced for the early diagnosis of the disease. Among these tests, the ELISA test based on detecting antigens has become the most commonly used test. It is known that the probability of ELISA to cross-react with parasites that carry similar immunogenic features and the similarities between antibodies generated in previous infections and new infections pose a challenge to making the definitive diagnosis. Therefore, it is reported that to predict the parasitic potential of the host and the success of treatment beforehand, the presence of Fasciola spp. antigens can be investigated in serum instead of antibodies. In conclusion, this study has established prevalence of fasciolosis in cattle raised in Van province using the copro-ELISA technique for the first time. It has been concluded that copro-ELISA could serve as a useful technique for herd diagnosis of fasciolosis in cattle in addition to fecal examinations particularly with respect to fasciolosis.
\end{abstract}

Keywords: cattle, Copro-ELISA, fasciolosis, Van, Turkey. 


\section{INTRODUCTION}

Fasciolosis, a serious infectious parasitic disease infecting domestic ruminants and humans, tops all the zoonotic helminthes worldwide [12]. Fasciola hepatica and Fasciola gigantica are the two parasitic species most commonly implicate as the etiological agents of the fasciolosis. F. hepatica has a worldwide distribution while $F$. gigantica is found on most continents primarily in tropical region [10].

In endemic regions, it is possible to base the diagnosis of fasciolosis on clinical signs and the season, however, it could be more useful to support these data with fecal examination and various hematologic and serological tests [1]. Also, it cannot detect infection at the prepatent period, because eggs are found in faeces when the flukes are already matured (usually between 10 and 12 weeks of infection) [25,33]. Thus, alternative immuno-serological methods have been developed for early diagnosis of fasciolosis. The ELISA test is easy to perform for herd monitoring at early stage of fasciolosis. Especially, the copro-ELISA test, based on determination of ES antigens in feces, has high specificity as confirmed by necropsy and high sensitivity as confirmed by lacking cross-reaction with antigens from other helminthes [25].

In Turkey, epidemiology studies on fasciolosis are mostly based on fecal examination or inspection at slaughterhouse, and few researchers have used immuno-serological methods[34,37,39,40]. Thus, the aim of this study was to determine the prevalence of fasciolosis in cattle in Van province by copro-ELISA technique.

\section{MATERIALS AND METHODS}

\section{Study area and animal sampling}

The study was conducted in 5 districts of Van province. The city is located at $42^{\circ} 40^{\prime} \mathrm{E}$ and $44^{\circ} 30^{\prime} \mathrm{E}$ longitude and $37^{\circ} 43^{\prime} \mathrm{N}$ and $39^{\circ} 26^{\prime} \mathrm{N}$ latitude, it is at an altitude of approximately $1,725 \mathrm{~m}$ and has close borders to eastern Iran [16]. Fecal samples from 140 cattle along with questionnaire based data on age, sex and breed were collected in directly from the rectum. Animals were grazed and watered on communal areas during the day and housed around households in barns at night.

\section{Coprological Examination}

The presence of $F$. hepatica eggs in faecal samples was evaluated by a sedimentation-flotation technique that was performed on $10 \mathrm{~g}$ of faeces. Briefly, the amount of faeces was weighed, mixed in with $200 \mathrm{~mL}$ water in a measuring cup and filtered 3 times through a tea sieve. The filtrate was allowed to stand for 30 min after which the sediment was collected in a test tube and centrifuged at $700 \times g$ for $3 \mathrm{~min}$. After centrifugation, the supernatant was removed, the sediment was suspended in zinc chloride (density 1.56) and centrifuged at $180 \times g$ for 3 min. Next, zinc chloride was added until a meniscus appeared on top of the test tube and the floating material was collected underneath a cover slip that was allowed to stand on the test tube for $\geq 2 \mathrm{~min}$. Finally, the samples were microscopically investigated under a $100 \times$ magnification [6]. The number of eggs per gram of fecal (EPG) was estimated according to a general method [7].

\section{Copro-ELISA detection of Fasciolosis}

A sandwich ELISA using Bio-X Bovine Fasciola hepatica Antigen ELISA Kit (Bio K 201) ${ }^{1}$ was performed on all faecal samples. Each individual faecal sample was homogenized with $2 \mathrm{~mL}$ dilution buffer (Bio K 201) $)^{1}$ by mixing with a pipette and vortexing. For cattle $2 \mathrm{~g}$ of each faecal sample was used. The homogenized samples were incubated overnight at $4^{\circ} \mathrm{C}$. Supernatant was collected from all samples after centrifugation for $10 \mathrm{~min}$ at $1000 \mathrm{~g}$ and stored at $-20^{\circ} \mathrm{C}$. The format of the ELISA plates was such that alternate wells (A,C,E and G) were sensitised with a specific polyclonal antibody againts Fasciola hepatica or left (B,D,F and H) unsensitised. Supernatants were incubated on the microplate for $2 \mathrm{~h}$ at $21^{\circ} \mathrm{C}$ $+/-3^{\circ} \mathrm{C}$. After this first incubation step, the plate was washed and incubated for $1 \mathrm{~h}$ with the first conjugate (a specific monoclonal antibody against an antigenic determinant of coupled to biotin), then the plate was incubated at $21^{\circ} \mathrm{C}+/-3^{\circ} \mathrm{C}$ for $1 \mathrm{~h}$. The plate was then washed, the second conjugate (a peroxidase-coupled avidine specific to biotin) was applied, and the plate was incubated at $21^{\circ} \mathrm{C}+/-3^{\circ} \mathrm{C}$ for another hour. After this second incubation, the plate was washed again and the enzyme substrate (hydrogen peroxide) ${ }^{1}$ and the chromogen (tetramethylbenzidine $)^{1}$ were added. The intensity of the resulting blue colour is proportionate to the sample's coproantigen titre. The optical densities in the microwells were evaluated spectrophotometrically (Bio-Tek Instruments, MicroQuant micropleyt reader $)^{2}$, using a $450 \mathrm{~nm}$ filter and the 
absorbance of the unsensitised well was subtracted from the absorbance of the sensitised well. Then the corrected absorbance values for each sample were divided by the corresponding positive control signal optical density and the results were multiplied by 100 to express it as a percentage.

\section{Statistical analysis}

Pearson's chi-square $\left(\mathrm{X}^{2}\right)$ test was performed to compare prevalence among sex, age and breed categories. Statistical comparisons were carried out using SPSS 22.0 statistical software.Significance was defined as $P<0.05$.

\section{RESULTS}

The overall prevalence of fasciolosis was $5.7 \%$ (8) and $30.7 \%$ (43) as assessed by the fecal egg examination and copro-ELISA method, respectively (Table 1). All positive results with fecal egg examination were also positive with copro-ELISA. The mean number of egg per gram of faeces (EPG) in infected cattle was 60.4 (min 16,6 max 100). The results of the association analysis of different factors with the prevalence of $F$. hepatica are presented in Table 2. Significant difference was found among cattle regarding age whereas no significant differences were found related to sex and breed.

Table 1. Diagnostic yield of fecal coproscopy and Copro-ELISA in detection of Fasciolosis in cattle.

\begin{tabular}{|c|c|c|c|c|c|c|c|c|c|}
\hline \multirow{2}{*}{ Local } & \multirow{2}{*}{$\begin{array}{c}\text { Examined cattle } \\
\mathrm{N}\end{array}$} & \multicolumn{2}{|c|}{ Infected cattle } & \multicolumn{2}{|c|}{$\begin{array}{c}\text { Copro ELISA (+) } \\
\text { Coproscopy }(+)\end{array}$} & \multicolumn{2}{|c|}{$\begin{array}{c}\text { Copro ELISA (+) } \\
\text { Coproscopy }(-)\end{array}$} & \multicolumn{2}{|c|}{$\begin{array}{c}\text { Copro ELISA (-) } \\
\text { Coproscopy (-) }\end{array}$} \\
\hline & & $\mathrm{N}$ & $\%$ & $\mathrm{~N}$ & $\%$ & $\mathrm{~N}$ & $\%$ & $\mathrm{~N}$ & $\%$ \\
\hline Van & 140 & 43 & 30.7 & 8 & 5.7 & 35 & $25^{*}$ & - & - \\
\hline
\end{tabular}

*Prevalence rate of prepatent Fasciola hepatica infections.

Table 2. Age, sex and breed related prevalence of Fasciola hepatica based on Copro-ELISA in cattle.

\begin{tabular}{cccccc}
\hline \multirow{2}{*}{ Parameter } & Examined cattle & \multicolumn{2}{c}{ Infected cattle } & $\chi^{2}$ & $P$ \\
& $\mathrm{~N}$ & $\mathrm{~N}$ & rate & & \\
\hline Age (years) & & & & & \\
\hline $1-2$ & 43 & 18 & $41.9^{\mathrm{a}}$ & & \\
$3-5$ & 77 & 24 & $31.2^{\mathrm{b}}$ & 0.732 & \\
$\geq 6$ & 20 & 1 & $5^{\mathrm{b}}$ & & \\
\hline Sex & & & & & \\
\hline Male & 17 & 6 & $35.3^{\mathrm{a}}$ & & \\
Female & 123 & 37 & $30.1^{\mathrm{a}}$ & & \\
\hline Breed & & & & & \\
\hline Brown Swiss & 45 & 18 & $40^{\mathrm{a}}$ & & \\
Simmental & 53 & 12 & $22.6^{\mathrm{a}}$ & 3.447 & \\
\hline Crossbreed & 42 & 13 & $31^{\mathrm{a}}$ & & \\
\hline Total & 140 & 43 & 30.7 & & \\
\hline
\end{tabular}

$\overline{\mathrm{a}, \mathrm{b}}$ The different letters within the same column indicate significant difference among groups. $\chi^{2}$ : Pearson's chi-squared test. 


\section{DISCUSSION}

It is known that parasitic diseases have an important place in cattle breeding in Turkey as they also have worldwide. Helminths account for a significant portion of parasitic diseases of cattle. The environmental and geographic conditions of Turkey are suitable for the development of most helminth species [35]. Particularly, the Fasciola spp. are distributed widely, and their intermediate hosts are snails of the Lymnaea genus. The causing agents of Fasciola also known as liver flukes are zoonotic trematodes that localize in the biliary ducts of various herbivores such as sheep, goats, and cattle. F. hepatica is the most common species of liver flukes, and its pathogenicity leads to significant impact on the economy of the livestock industry. The economic losses consist of costs of anthelmintics, drenches, labor, liver condemnation at meat inspection; and losses in production due to mortality, reduction in meat, milk and reduction in growth rate, fertility and decreased feed intake, conversion and lower resistance to other disease [15,32].

The prevalence of the disease in cattle in different countries is variable depending on some factors such as the region's soil structure, precipitation, and seasons [34]. It has been reported that this disease is prevalence by rates of $10.9 \%$ in cattle in North India [11], 25.5\% in Pakistan [17], 75\% in France [9], 4.9\% in Greece [21], $11.1 \%$ in Italy [8], 75\% in Brazil [3], $18 \%$ in Switzerland [13], 3.3\% in Iraq [23], 45.6\% in Cameroon [27], 27.7\% in Nigeria [22], and 3.68\% in Iran [19]. Although most of the studies conducted on bovine fasciolosis in Turkey used conventional methods [17,38], serological studies have also been performed to determine prevalence $[34,39,40]$. It is reported that the prevalence of fasciolosis calculated by different detection methods is between $0.5 \%$ and $69.2 \%$ in cattle in several regions of Turkey $[4,39,40]$. However, to the best of our knowledge, no investigation has been conducted to determine prevalence of bovine fasciolosis in Van province in Turkey. This study is the first to investigate fasciolosis with the copro-ELISA technique in cattle raised in Van province, Turkey. In the present study, the prevalence of fasciolosis in cattle was determined as $30.7 \%$ and $5.7 \%$ by the coproELISA and fecal egg examination, respectively. These results are conformity with some findings reported from different regions of Turkey [5,20], and it was concluded that the little differences present are because the studies were conducted in different cities.

The primary risk factor that affects the prevalence of fasciolosis is the animal's age. Although it is recorded that the infection risk varies depending on the age factor, cattle in advanced ages ( $>2-3$ years) are more prone to fasciolosis than those in younger ages $(<2$ years) $[24,26,31,39]$. In the present study, the highest prevalence was observed in the age group of $1-2$ years as $41.9 \%$, and this was followed by $31.2 \%$ in the age group of 3-5 years and 5\% in the age group of $\geq 6$ years. The result of present study showed that age has significant effect $(P<0.05)$ on the prevalence of bovine fasciolosis, being higher in young animals than the adult. There was a decrease in infection rate as age increased. This may be due to the result of acquired immunity with age which is manifested by humoral immune response and tissue reaction in bovine liver due to previous challenge. There are some additional reports confirming that the increased resistance against fasciolosis (low prevalence) with age is most likely related to the effect of acquired immunity in adult cattle or liver fibrosis which prevention the passage of immature flukes by the calcification of the bile ducts $[2,29,30]$.

It is reported that gender has no effect on fasciolosis in cattle or this parasite is generally more common in female than male [2,29,31,34]. The higher percentage of infection in the females can't be explained exactly but it might be assumed that hormonal influence as well as stress leading to immunesuppression may be associated with this phenomenon [31]. However, it has been reported that significantly higher prevalence rates in males [26]. In the present study, the fecal examination was positive in 6 of the 17 male cattle and 37 of the 123 female cattle tested by copro-ELISA. The result of present study revealed that the sex of animals did not have significant effect $(P>0.05)$ on the occurrence of bovine fasciolosis.

It was reported that the prevalence based on copro-ELISA technique as 3.48, 2.81 and $2.43 \%$ in Holstein, Simmental and Brown Swiss breed cattle, respectively [34]. They showed that there was no statistical difference between infection rates in relation to breed. In Kayseri, was reported that Fasciola spp. antibodies as $68.6 \%$ in Holstein, as $76.9 \%$ in Simmental, as $58.8 \%$ in Brown Swiss breed, and as $70.9 \%$ crossbred cattle breeds [39]. Researchers re- 
corded that there was no statistical difference between the infection rates in relation to breed. Likewise, in this study Fasciola spp. antigens were identified at rates of $40 \%$ in Brown Swiss, 31\% in Crossbreds, and $22.6 \%$ in Simmental. The difference between breeds did not show significant differences in prevalence of F. hepatica.

One study used that the ELISA test to detect F. hepatica antigens in the feces of cattle and sheep [25]. Their review of the test results yielded a $38.8 \%$ positivity even in feces of cattle in which $F$. hepatica eggs were not detected. The same researchers reported that the fasciolosis could be detected at its early phases by this method that is highly sensitive. Similarly, in another study found that the sensitivity of the copro-ELISA test used to detect fasciolosis in cattle was 94\% [6]. Previous study investigated that the sensitivity and specificity of the copro-ELISA method in sheep, cattle, and horses infected with $F$. hepatica in Western Australia [28]. They determined that its specificity as $100 \%$, and its sensitivity as $100 \%$ in sheep, $87 \%$ in cattle, and $28 \%$ in horses. Researchers report that the copro-ELISA method is quite sensitive in detecting the presence of fasciolosis in cattle and sheep, but in horses, they recommend that using the sedimentation method because the sensitivity of ELISA is lower than $30 \%$ for horses. It was examined that 198 cattle in the Derinkuyu district of Nevsehir with respect to fasciolosis using the coproELISA method [34]. They identified a 3.03\% rate of positivity. In the current study, to detect fasciolosis in cattle, the copro-ELISA test which is defined as an alternative method of detecting excrete/secrete antigens of $F$. hepatica in feces on microplates covered with polyclonal antibodies was used. The infection rate that was identified as $5.7 \%$ by fecal examination was found to be $30.7 \%$ by coproantigen ELISA. This result shows that the copro-ELISA test is more specific than fecal examination.
To diagnose fasciolosis, eggs can only be detected in feces after the tenth or twelfth week of infection once the parasites have matured. It is reported that routine microscopic methods used before this stage do not provide sufficient information about the current infection status. Therefore, serological tests have been introduced for the early diagnosis of the disease [34]. Among these tests, the ELISA test based on detecting antigens has become the most commonly used test. It is known that the probability of ELISA to cross-react with parasites that carry similar immunogenic features and the similarities between antibodies generated in previous infections and new infections pose a challenge to making the definitive diagnosis. Therefore, it is reported that to predict the parasitic potential of the host and the success of treatment beforehand, the presence of Fasciola spp. antigens can be investigated in serum instead of antibodies [14].

\section{CONCLUSIONS}

In conclusion, this study has established prevalence of fasciolosis in cattle raised in Van province using the copro-ELISA technique for the first time. It is important to use the copro-ELISA test which has high sensitivity and specificity for prepatent infections that may be overlooked by fecal examination methods. It has been concluded that copro-ELISA could serve as a useful technique for herd diagnosis of fasciolosis in cattle in addition to fecal examinations particularly with respect to fasciolosis.

\section{MANUFACTURERS}

${ }^{1}$ Bio-X Diagnostics. Jemelle, Belgium.

${ }^{2}$ BioTek Instruments Inc. Winooski, VT, USA.

Funding. This work was supported financially by a grant from Yüzüncü Yıl University Scientific Research Projects (YYUBAP/2015-SBE-YL024).

Declaration of interest. The authors report no conflicts of interest. The authors alone are responsible for the content and writing of the paper.

\section{REFERENCES}

1 Abunna F., Asfaw L., Megersa B. \& Regassa A. 2010. Bovine fasciolosis: coprological, abattoir survey and its economic impact due to liver condemnation at Soddo municipal abattoir, Southern Ethiopia. Tropical Animal Health and Production. 42: 289-292.

2 Addis G., Adina K. \& Jemberu A. 2015. Prevalence and economic importance of bovine fasciolosis in Dembi Dolo municipal abattoir, south-western Ethiopia. International Journal of Agricultural Sciences and Veterinary Medicine. 1: 33-36. 
3 Busetti E.T., Paske A., Ruis M.C.E., Thomaz V. \& Golinelli A. 1983. Helminth parasites of Bubalis bubalis in Parana State, Brazil. Arquivo Brasileiro de Medicina Veterinária e Zootecnia. 35(3): 399-404.

4 Celep A. 1984. Samsun ve Ordu illeri ile ilçelerinde sığırlarda gaita muayene sonuçlarına göre tespit edilebilen helmintolojik bulgular ve perifer kan frotisi muayene sonuçları. Etlik Veteriner Mikrobiyoloji Dergisi. 6: 106-112.

5 Celep A., Acici M., Cetindag M., Coskun S.Z. \& Gursoy S. 1990. Samsun yöresi sı urlarında helmintolojik ara tırmalar. Etlik Veteriner Mikrobiyoloji Dergisi. 6: 117-130.

6 Charlier J., Duchateau L., Claerebout E., Williams D. \& Vercruysse J. 2008. Qualitative and quantitative evaluation of coprological and serological techniques for the diagnosis of fasciolosis in cattle. Veterinary Parasitology. 153: 44-51.

7 Conceição M.A., Durão R.M., Costa I.H. \& da Costa J.M. 2002. Evaluation of a simple sedimentation method (modified McMaster) for diagnosis of bovine fasciolosis. Veterinary Parasitology. 105(4): 337-343.

8 Cringoli G., Rinaldi L., Veneziano V., Capelli G. \& Malone J.B. 2002. A cross-sectional coprological survey of liver flukes in cattle and sheep from an area of the southern Italian Apennines. Veterinary Parasitology. 108(2): 137-143.

9 Dorchies P., Ducos L., Pangui L.J. \& Alzieu J.P. 1988. Prevalence of Fasciola hepatica, Dicrocoelium lanceolatum and Linguatula denticulata in cattle livers condemned at Pamiers abattoir (Ariege, France). Revue de Médecine Vétérinaire. 139(39): 307-309.

10 Farag H.F. 1998. Human fascioliasis in some countries of the Eastern Mediterranean Region. Eastern Mediterranean Health Journal. 4(1): 156-160.

11 Garg R., Yadav C.L., Kumar R.R., Banerjee P.S., Vatsya S. \& Godara R. 2009. The epidemiology of fasciolosis in ruminants in different geo-climatic regions of North India. Tropical Animal Health and Production. 41: 1695.

12 Haridy F.M., Morsy T.A., Gawish N.I., Antonios T.N. \& Abdel Gawad A.G. 2002. The potential reservoir role of donkeys and horses in zoonotic fascioliasis in Gharbia Governorate, Egypt. Journal of the Egyptian Society of Parasitology. 32(2): 561-570.

13 Rapsch C., Schweizer G., Grimm F., Kohler L., Bauer C., Deplazes P., Braun U. \& Torgerson P.R. 2006. Estimating the true prevalence of Fasciola hepatica in cattle slaughtered in Switzerland in the absence of an absolute diagnostic test. The International Journal for Parasitology. 36(10-11): 1153-1158.

14 Hillyer G.V. 1999. Immunodiagnosis of human and animal fasciolosis. In: Dalton J.P. (Ed). Fasciolosis. Cambridge: University Press, pp.435-443.

15 Hossain M.M., Paul S., Rahman M.M, Hossain F.M.A, Hossain M.T. \& Islam M.R. 2011. Prevalence and economic significance of caprine fascioliasis at Sylhet district of Bangladesh. Pakistan Veterinary Journal. 31: 113-116.

16 Kalelioglu E. 1991. Characteristics of the climate of Van Plain (Van Ovasının iklim özellikleri). Ankara Üniv. Dil Tarih-Coğrafya Fakültesi Dergisi. 35: 155-166.

17 Kara M., Gicik Y., Sari B., Bulut H. \& Arslan M. 2009. A slaughter house study on prevalence of some helminths of cattle and sheep in Malatya province, Turkey. Journal of Animal and Veterinary Advances. 8: 2200-2205.

18 Khan M.K., Sajid M.S., Khan M.N., Iqbal Z. \& Iqbal M.U. 2009. Bovine fasciolosis: prevalence, effects of treatment on productivity and cost benefit analysis in five districts of Punjab, Pakistan. Research in Veterinary Science. 87 : 70-75.

19 Khoramiana H., Arbabia M., Osqoib M.M., Delavaria M., Hooshyara H. \& Asgaric M. 2014. Prevalence of ruminants fascioliasis and their economic effects in Kashan, center of Iran. Asian Pacific Journal of Tropical Biomedicine. 4(11): 918-922.

20 Kurtpınar H.J. 1957. Erzurum, Kars ve Ağrı vilayetleri sığır, koyun ve keçilerin yaz aylarına mahsûs parazitleri ve bunların do urdukları hastalıklar. Türk Veteriner Hekimleri Derneği Dergisi. 27: 3320-3325.

21 Liakos V. 1985. Epidemiological investigations of parasitoses of small ruminants, Ellenike Kteniatrike. Journal of the Hellenic Veterinary Medical Society. 28(2): 82-84.

22 Magaji A.A., Ibrahim K., Salihu M.D., Saulawa M.A., Mohammed A.A. \& Musawa A.I. 2014. Prevalence of Fascioliasis in Cattle Slaughtered in Sokoto Metropolitan Abattoir, Sokoto, Nigeria. Advances in Epidemiology. 11: 5.

23 Mahdi N.K. \& Al-Baldawi A.K. 1987. Hepatic fascioliasis in the abattoirs in Basrah. Annals of Tropical Medicine and Parasitology. 81(4): 377-379.

24 Maqbool A., Hayat C.S., Akhtar T. \& Hashmi H.A. 2002. Epidemiology of fasciolosis in buffaloes under different managemental conditions. Veterinarski arhiv. 72: 221-228. 
25 Mezo M., Gonzalez-Warleta M. \& Ubeira F.M. 2007. Theuse of MM3 monoclonal antibodies for the early immunodiagnosis of ovine fascioliasis. Journal of Parasitology. 93: 65-72.

26 Mufti S., Afshan K., Khan I.A., Irum S., Qureshi I.Z., Rizvi S.S.R., Mukhtar M., Mushtaq M., Iqbaland Z. \& Qayyum M. 2015. Serological and coprological studies of bovine fasciolosis in the Pothwar region. Pakistan Veterinary Journal. 35(2): 178-182.

27 Nfi A.N. \& Alongé D.O. 1987. An economic survey of abattoir data in Fako division of the South West province, Cameroon. Bulletin of Animal Health and Production in Africa. 35: 239-242.

28 Palmer D.G., Lyon J., Palmer M.A. \& Forshaw D. 2014. Evaluation of a copro-antigen ELISA to detect Fasciola hepatica infection in sheep, cattle and horses. Australian Veterinary Journal. 92: 357-361.

29 Petros A., Addisu K. \& Amanuel W.J. 2013. Prevalence and economic significance of bovine fasciolosis in Nekemte Municipal abattoir. Journal of Veterinary Medicine and Animal Health. 5(8): 202-205

30 Radostits D., Blood B.\&Gray C. 1994. Vet medicine text book of the diseases of cattle, sheep, goat, pig and horse. 8th edn. London: Baillere - Tindall, pp.1015-1026.

31 Rezaul K., Mohammad S.M. \& Giasuddin M.D. 2015. Epidemiological Study of ovine Fasciolosis: Prevalence and Risk Factor Assessment at Shahjadpur Upazila of Bangladesh. Immunology and Infectious Diseases. 3(3): 25-29.

32 Rokni M.B., Mirhendi M., Behnia M., Harandi M.F. \& Jalalizand N. 2010. Molecular characterization of Fasciola hepatica isolates by RAPD PCR and ribosomal ITSI sequencing. Iran. Iranian Red Crescent Medical Journal. 12: 27-32.

33 Salimi-Bejestani M.R., McGarry J.W., Felstead S., Ortiz P., Akca A. \& Williams D.J. 2005. Development of an antibody-detection ELISA for Fasciola hepatica and its evaluation against a commercially available test. Research in Veterinary Science. 78: 177-181.

34 Sen M., Yildirim A., Biskin Z., Duzlu O. \& Inci A. 2011. Derinkuyu Yöresindeki Sığırlarda Fasciolosis in KoproELISA ve Dışkı Muayene Yöntemleriyle Araştırılması. Turkiye Parazitoloji Dergisi. 35: 81-85.

35 Senlik B. 2013. Fasciolosis. Özcel M.A. (Ed). In: Veteriner Hekimliğinde Parazit Hastalıkları Cilt 1. İzmir. Türkiye Parazitoloji Derneği. 24: 165-178.

36 Simsek S., Koroglu E., Utuk A.E.\&Altay K. 2006. Use of Indirect Excretory/ Secretory Enzyme-Linked Immunosorbent Assay (ES-ELISA) for the Diagnosis of Natural Fasciola hepatica Infection in Eosinophilic and Non-Eosinophilic Cattle from Eastern Turkey. Turkish Journal of Veterinary and Animal Sciences. 30: 410-415.

37 Simsek S., Risvanlı A., Utuk A.E., Yuksel M., Saat N. \& Koroglu E. 2007. Evaluation of relationship between repeat breeding and Fasciola hepatica and hydatidcyst infections in cows in Elazig district of eastern Turkey. Research in Veterinary Science. 83: 102-104.

38 Toparlak M., Tasçı S. \& Gül Y. 1989. Van ili belediye mezbahasında kesilen sı̆̆ırlarda karaciğer trematod enfeksiyonları. Ankara Üniversitesi Veteriner Fakültesi Dergisi. 36: 419-423.

39 Yavuz A., Inci A., Yildirim A., Ica A. \& Duzlu O. 2007. Sığırlarda Fasciola hepatica’ nın Yayılışı. Sağllk Bilimleri Dergisi. 16: 96-102.

40 Yildirim A., Ica A., Duzlu O. \& Inci A. 2007. Prevalence and Risk Factors Associated with Fasciola hepatica in Cattle from Kayseri Province, Turkey. Revue de Médecine Vétérinaire. 158: 613-617. 